\title{
Maahanmuuttajat digivertaisohjaajina
}

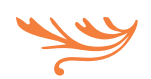

Mahdollisuus toimia aktiivisena vaikuttajana yhteiskunnassa on merkittävä, maahanmuuttajan kotoutumista edistävä tekijä. Vertaisryhmätoiminta ja vertaisohjaus ovat yksi tapa osallistua aktivoivaan toimintaan.

Digitaitojen hallitseminen vaatii jokaiselta jatkuvaa osaamisen päivittämistä. Näitä taitoja tarvitsevat myös maahanmuuttajat arjessa, opiskelussa ja työssä voidakseen kotoutua suomalaiseen yhteiskuntaan. Digitaitojen oppimiseen on erilaisia menetelmiä ja koulutuksia, joita toteutetaan sekä lähi- että verkkoopetuksena. Maahanmuuttajien digitaitojen oppimisen haasteita pohtineiden Maarit Mäkisen ja Mika Sihvosen (2016) mukaan tietotekniikan opetusta olisi hyödyllistä sisällyttää jo maahanmuuttajien alkuvaiheen opetukseen kielenopetuksen rinnalle.

Opintokeskus Siviksen ja Seinäjoen koulutuskuntayhtymä Sedun toteuttamassa Digipolku töihin -hankkeessa digitaitoja opittiin vertaisoppimisen keinoin maahanmuuttajien toimiessa vertaisohjaajina toisille maahanmuuttajille. Maahanmuuttajataustaisilta vertaisohjaajilta kerätyn aineiston tarkastelu osoitti, millaisia ennakkokäsityksiä heillä oli omasta ohjaajuudestaan ja millaisia merkityksiä ohjaajuudella heille oli. Hanke toteutettiin
Euroopan sosiaalirahaston (ESR) rahoituksella vuosina 2017-2019.

\section{MAAHANMUUTTAJAT DIGIPOLKU TÖIHIN -HANKKEESSA}

Digipolku töihin -hankkeen tavoite oli opettaa ammatillisessa koulutuksessa ja työelämässä tarvittavia digitaitoja maahanmuuttajille vertaisoppimisen avulla. Kohderyhmänä olivat maahanmuuttajat, joilla oli oleskelulupa ja jotka kykenivät osallistumaan ryhmän toimintaan suomen kielellä.

Hankkeessa toteutettiin kaksi kolmen opintopisteen laajuista vertaisohjaajakoulutusta, minkä jälkeen vertaisohjaajiksi kouluttautuneet ohjasivat pareittain 8-17 hengen vertaisryhmiä omilla asuinpaikkakunnillaan. Ryhmät kokoontuivat keskimäärin 24 oppitunnin ajan Helsingissä, Kauhajoella, Lapualla, Oulussa, Seinäjoella ja Ähtärissä. Niissä opittiin suomen kielellä keskeisiä digitaitoja oppijoiden lähtötason, 


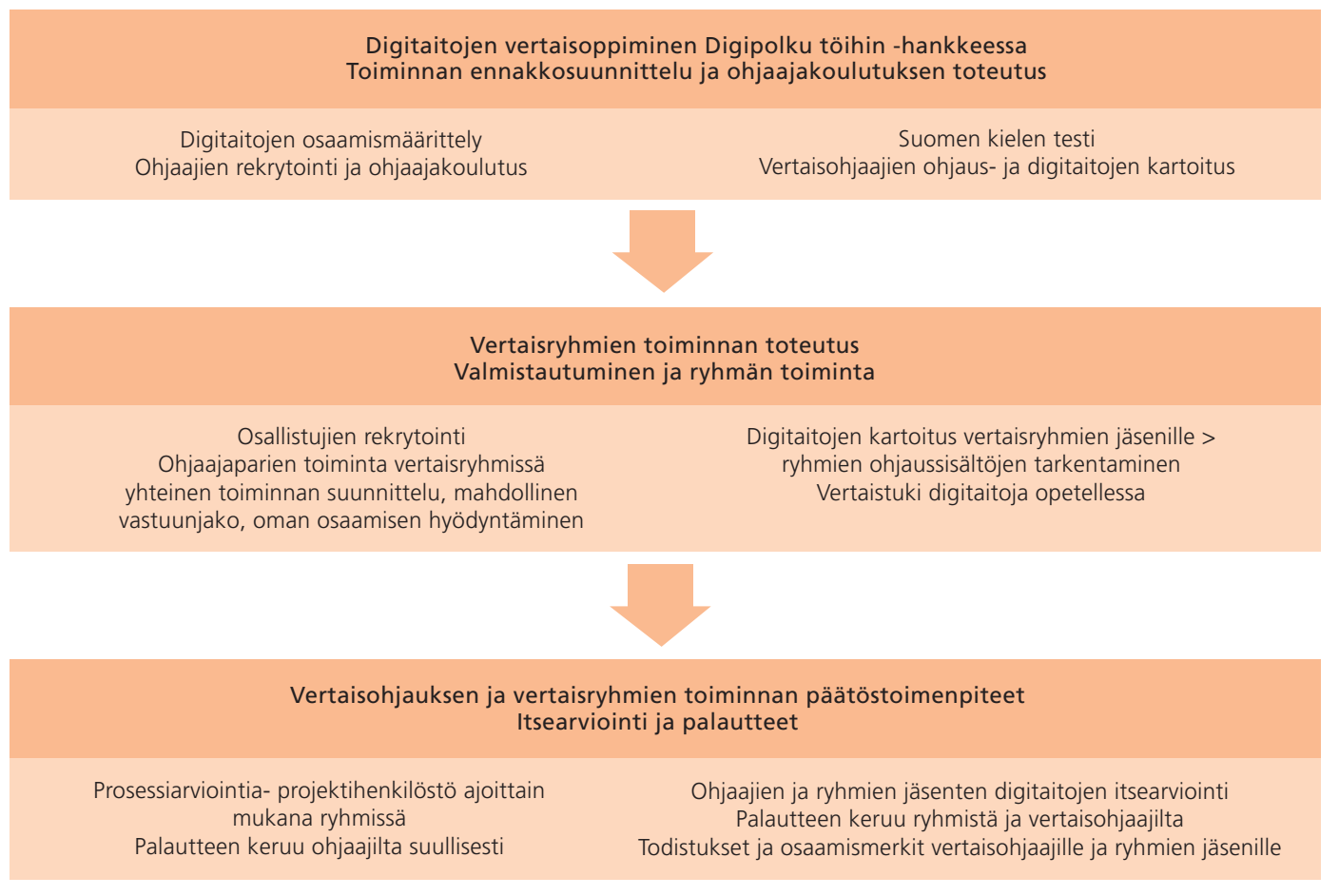

Kuvio 1. Digipolku töihin -hankkeen vertaisohjauksen ja -ryhmien toiminnan vaiheittaiset toimet.

tavoitteiden ja kiinnostuksen kohteiden mukaan (kuvio 1).

Hanketyöntekijät tukivat ohjaajia: he laativat materiaalia ohjaajille ja vertaisryhmille ja olivat tarvittaessa tavoitettavissa. Hankkeen päätyttyä vertaisryhmissä hyödynnetyt materiaalit koottiin verkkoon (https://www.ok-sivis.fi/digipolku-toihin.html). Vertaisohjaajat olivat vapaaehtoisia, eikä heille maksettu palkkiota mahdollisia matkakuluja lukuun ottamatta.

Ryhmissä käsiteltäviä digisisältöjä valittaessa käytettiin pohjana Tietoyhteiskunnan kehittämiskeskuksen (TIEKE) Tietokoneen käyttäjän A-kortin osaamisvaatimuksia ja Tiviittori-palvelun määritelmiä, joissa digitaidot jaetaan tietoyhteiskunta- ja mediataitoihin sekä teknis-käytännöllisiin taitoihin ja tietotyön taitoihin (TIEKE 2018).

Tieto- ja viestintätekniset perustaidot ovat tärkeitä sekä ammatillisissa koulutuksissa että työelämässä etenemiselle. Digisisältöjen määrittelystä keskusteltiin maahanmuuttajia työllistävän yrityksen edustajien kanssa. Digisisältöihin kuului myös työnhakua, sitä koskevien asiakirjojen laadintaa ja tutustumista verkkopalveluihin. Vertaisohjaajat varautuivat ottamaan huomioon ryhmäläisten osaamisen ja mukauttamaan digisisältöjä ryhmän etenemisvauhdin mukaisesti.

\section{VERTAISOHJAAJIEN VALINTA}

'Maahanmuuttajalla' tarkoitetaan tilastoissa ja tutkimuksissa yleisesti käytetyn määritelmän mukaisesti ulkomaalaista, joka asettuu asumaan kotimaansa ulkopuolelle muuten kuin tilapäisesti. Hankkeessa vertaisohjaajiksi kouluttautuvilta maahanmuuttajilta vaadittiin suomen kielen taitoa, kokemusta digitaalisten perustaitojen käytöstä, vuorovaikutus- ja ryhmätyötaitoja sekä kiinnostusta ja myönteistä asennetta ohjaustyöhön. Koska vertaisryhmätoiminta toteutettiin suomeksi, ohjaajien kielitaitokriteeriksi asetettiin Eurooppalaisen viitekehyksen taitotasoasteikon mukainen taitotaso B1 eli Yleisten kielitutkintojen taitotaso 3 (Opetushallitus 2012). B1-tasoa kuvataan 
kynnystasoksi: kielenkäyttäjä pystyy jo toimimaan itsenäisesti suullisissa ja kirjallisissa viestintätilanteissa (Pöyhönen, Tarnanen, Kyllönen, Vehviläinen \& Rynkänen 2009, 13). Lähtöoletus oli, että ohjattavien kielitaitotaso olisi alempi kuin ohjaajien.

Ohjaajien rekrytoinnissa tehokkaimmaksi menetelmäksi osoittautui henkilökohtainen yhteydenotto tai tapaaminen, jonka aikana rekrytoitavalle kyettiin helpotetulla suomen kielellä selvittämään ohjaajakoulutuksen ja vertaisryhmän ohjauksen lähtökohdat, tavoitteet, vaatimukset ja sisältö. Vertaisohjaajiksi valituilla oli erilainen kulttuuritausta, peruskoulutus ja kokemus ohjaamisesta. Ohjaajat olivat oleskelleet Suomessa parista vuodesta lähes kymmeneen vuoteen.

\section{VERTAISET OPPIMASSA TOISILTAAN}

Digipolku töihin -hankkeessa vertaisohjaaja toimi sekä ryhmän jäsenten että vertaisohjaajaparinsa tukena jakaen tietojaan ja kokemuksiaan. Hankkeen toiminta, käytännössä ohjaajien parityöskentely ja vertaisryhmät, perustui oleellisesti vertaisuuteen ja vertaisoppimiseen. Vertaisuus toteutui hankkeessa seuraavilla tavoilla:

- Vertaisohjaajat olivat maahanmuuttajataustaisia ja siten vertaisia keskenään toimiessaan pareittain vertaisryhmiensä ohjaajina.

- Vertaisohjaajat ja -ryhmien jäsenet olivat vertaisia siinä, että he olivat maahanmuuttajia, ja suomi oli heille vieras kieli.

Vertaisuutta voidaan määritellä monella tavalla. Digipolku töihin -hankkeessa olennaista oli se, miten osallistujat itse kokivat vertaisuuden. Perehdytysjakson aikana ohjaajat ymmärsivät vertaisuutensa perustan, mitä pidetään vertaisryhmien edellytyksenä (SunWolf 2008, 19). Maahanmuuttajuuden perusteella he kokivat olevansa yhdenvertaisia toistensa kanssa.

Vertaisryhmien toiminnan aikana ryhmän jäsenet ja ohjaajat tunsivat olevansa maahanmuuttajina keskenään tasa-arvoisia, ja heitä yhdisti kiinnostus oppia digitaitoja.Vertaisryhmän jäsenillä on jonkin tekijän, esimerkiksi kykyjen tai taustan, suhteen vertaisuudesta pääasiallisesti jaettu yhdenmielisyys (SunWolf 2008, 2).
Vertaisoppimisessa jotakin asiaa opiskellaan yhdessä niin, että oppijat ovat samanarvoisia. Sen muotoja ovat vertaisohjaus ja yhteistoiminnallisuuteen perustuva opiskelu (Topping 2005, 632). Vertaisryhmässä taidoiltaan osaavampi voi ohjata vähemmän osaavaa, mutta vertainen koetaan usein helpommin lähestyttäväksi kuin opettaja. 'Vertaisoppimisella' voidaan viitata tavoitteelliseen opiskeluun, mutta käsite voi myös viitata epämuodolliseen, jonkin ryhmän yhteisen ongelman ratkaisemiseen tähtäävään toimintaan (Fields 2012, 9; Fawcett \& Garton 2005). Kaikkien vertaisryhmien ei tarvitse toimia samoilla periaatteilla, vaan kukin ryhmä löytää itselleen sopivat toimintatavat (Nylund 2005, 207).

Vertaisohjaajilta edellytettiin lisäksi ohjattavan tilannetta ymmärtävää asennetta ja omaa kokemusta aikuisena oppimisesta. Yhteisten kokemusten vuoksi osallistujat kokevat tulevansa paremmin ymmärretyiksi toistensa kanssa (Nylund 2005). Kullakin vertaisohjaajalla oli erilainen kulttuuritausta, koulutus, työhistoria, äidinkieli, oppimiskäsitys ja persoonallisuus sekä erilaisia elämänkokemuksia, kukin ohjaaja oli erilainen.

Vertaistoimintaan osallistumisessa syntyy osaamista ja sitä välittyy, kun toimijat jakavat erilaisia perspektiivejä (Kentz, Sintonen \& Lipponen 2017). Osallistumisesta ei kuitenkaan välttämättä seuraa osallisuuden tunnetta.

Elina Nivala ja Sanna Ryynänen (2013) ovat tarkastelleet sosiaalipedagogiikan näkökulmasta osallistumisen ja osallisuuden käsitteitä sekä niiden monitulkintaisuutta. Heidän mukaansa osallisuus on tietyt laadulliset kriteerit täyttävää osallistumista. Se on vahvasti kokemuksellista, jäsenyyden tunnetta ja mukana olemista yhteisön elämässä ja toiminnassa. Osallisuus on sisäpuolelle pääsemistä ja huomioonotetuksi tulemista, eikä se perustu vain siihen, että on mukana osallistumassa. Pikemminkin se perustuu osallistujien tietämykseen, sitoutuvaan vastuunottoon ja vaikutusvaltaan. Osallistujat ovat mukana jakamassa tietämystään aidosti omalla panoksellaan.

Digipolku töihin -hankkeessa kysyttiin 17 vertaisohjaajalta, millaiseksi he ennakoivat vertaisohjaajana toimimisen ja millaisena he sen vertaisryhmätoiminnan jälkeen kokivat. Aineistoa kerättiin kyselylomakkeilla, ja joillekin tehtiin lisäksi tarkentavia haastatteluja. Vastauksia saatiin 12 vertaisohjaajalta. 


\section{NÄKEMYKSIÄ OMASTA OHJAAJUUDESTA ENNEN VERTAISOHJAAJANA TOIMIMISTA}

Ennen kuin vertaisryhmien toiminta käynnistyi, ohjaajat luottivat vastaustensa mukaan sekä omaan digiosaamiseensa että ohjaustaitoihinsa. Joillakin ohjaajilla oli pedagoginen koulutus ja työkokemusta syntymämaastaan, kun taas muutamalla oli harrastuksissa hankittua ohjaajakokemusta. Monille digitaitojen oppimisen ohjaus oli kuitenkin uusi kokemus.

Ohjaajat kokivat, että hyvin erilaisista kokemuksista oli hyötyä ryhmän ohjaamisessa. Eräs ohjaaja esimerkiksi arveli jopa, että vuosien mittainen ruumiillinen työ oli ohjaajan tehtävässä voimavara. Vertaisohjaajat tunsivat myös epävarmuutta, mutta he uskoivat kuitenkin onnistuvansa ohjaustehtävässään.

Vertaisohjaajat arvioivat lisäksi omia vahvuuksiaan ja ominaisuuksia, joita he ajattelivat ohjaajan tarvitsevan. Ohjaajat kuvailivat itseään avoimiksi, reippaiksi, huomaavaisiksi, sosiaalisiksi, tunnollisiksi tai itsenäisiksi ohjaajiksi. He pitivät tärkeinä kärsivällisyyttä, kuuntelemisen taitoa ja hyviä kommunikointitaitoja.

Eräs ohjaaja kuvasi ominaisuuksiaan ja ohjausvastuuta oppimisesta seuraavasti:

”Reipas ja avoin - pitää pysytä olla kärsivällinen [--] mutta samalla saada opiskelijat ymmärtämään että on tärkeä oppia näitä." (Ohjaaja 5)

Asennetasolla vertaisohjaajat arvelivat osaavansa asettua oppijan tilanteeseen ja ymmärtävänsä digitaitoja opiskelevaa, koska olivat olleet ja edelleen olivat itsekin oppijan roolissa. Parasta omissa oppimiskokemuksissa oli ollut mahdollisuus tehdä itselle tärkeitä asioita ja saada yksilöllistä ohjausta, minkä mukaan ohjaajat itsekin aikoivat toimia. Oppijoiden aktiivisuus ja halu oppia helpottaisi ohjaajien mielestä yhteistyötä.

Eräs vertaisohjaaja oli valmis auttamaan erityisesti toisia maahanmuuttajia oppimaan digitaitoja.

"Olen valmis jakamaan ja auttamaan omasta [-toiselle maahanmuuttajalle." (Ohjaaja 8)

Ohjaajat pitivät itseään nimenomaan ohjaajina tai avustajina, eivät opettajina. He kertoivat voivansa olla vertaisryhmäläisten kanssa hyviä ystäviä. Ohjaajat toivoivat osaavansa kannustaa ja motivoida vertais- ryhmäläisiä oppimaan tietokoneen käyttötaitoja ja pohtivat ohjauksensa pedagogisia ratkaisuja, sillä heille oli tärkeää, että oppijat parantaisivat digitaitojaan. Eräs ohjaaja kuvasi aikeitaan seuraavasti:

"Olen tällainen oleva vertaisohjaaja joka haluaisi opettaa hauskalla ja rennolla tavalla. Opetuksen tavoite on se, että kaikki saavat jotain [-]. En halua, että opiskelija istuu vain penkillä koko ajan. Sen sijaan haluaisin aina keksiä jotain pikkupelejä, kilpailuja [--] sil tavalla opiskellaan." (Ohjaaja 2)

Ohjaaja oli omakohtaisesti pohtinut myös sitä, miten oppimisesta saadaan paitsi hyödyllistä myös mielenkiintoista.

\section{DIGITAITOJA JA SUOMEN KIELTÄ OPPIMASSA}

Digisisältöjen ohjaamiseen vaikuttivat keskeisesti ryhmän jäsenten erilaiset ennakkotiedot ja taidot. Tekstinkäsittely oli toisten ohjaajien mielestä helppo ja toisten mukaan vaikea aihe. Ero vastauksissa johtui vertaisryhmäläisten erilaisesta osaamisesta. Ohjaustyön yhtenä haasteena ohjaajat pitivätkin vertaisryhmäläisten erilaista digiosaamisen lähtötasoa.

”Ryhmä oli sekoittunut: 1 osaa kaikki täydellisesti, 2 ei osaa mitään, muut osaavat puoli tai jotakin." (Ohjaaja 11)

Sähköpostin käyttöönotto taas vaati harjoitusta ja ohjaajien tukea. Monilla oli entuudestaan sähköposti käytössä, joten sen harjoittelu yhdistyi suomen kielen harjoitteluun. Joidenkin ryhmien osallistujat taas tekivät elämänsä ensimmäisen sähköpostiosoitteen. Sosiaalisen median käyttäminen ja virtuaaliseen verkko-oppimisympäristöön tutustuminen vaativat kahden ohjaajan mukaan eniten ohjausta. Ohjaajan näyttämä esimerkki ja erityisesti käytännön harjoitukset kehittivät ohjaajan mukaan oppijoiden taitoja.

Ohjaajat kokivat vuorovaikutuksen ohjattavien kanssa haastavaksi, sillä ohjauksessa käytetty suomen kieli ei ollut sen paremmin ohjaajien kuin vertaisryhmäläisten äidinkieli. Ohjauksessa pyrittiin avaamaan ja käyttämään nimenomaan alan suomenkielisiä termejä. Kirjallisissa tehtävissä, kuten tiedonhaussa ja työhakemusten laadinnassa, ohjaajilta vaadittiin erityistä 
kielellistä perehtymistä käsiteltäviin teemoihin. Muutama vertaisohjaaja käytti apunaan englantia, mutta ryhmien pääasiallinen kieli oli suomi, koska läheskään kaikki osallistujat eivät osanneet englantia.

"Ryhmäläisten kielitaitojen takia ryhmä meni hitaalla tahdilla." (Ohjaaja 7)

Koska vertaisryhmät olivat sekä digitaidoiltaan että suomen kielen taidoiltaan heterogeenisia, ohjaajilta edellytettiin oman kielenkäytön tarkkailemista ja sovittamista kunkin ohjattavan tasolle. Moni ohjaaja koki onnistumisen iloa siitä, että sai tehtyä itsensä ymmärretyksi suomen kielellä.

\section{OHJAAJANA KYPSYMINEN VERTAISOHJAUKSEN AIKANA}

Ryhmien toiminnan päätyttyä ohjaajat kertoivat saaneensa ohjauskokemusta ja pystyneensä tukemaan ryhmän jäsenten digitaitojen kehittymistä.

Ryhmän jäsenet oppivat uusia digitaitoja, jotka helpottavat arjen toimintoja, opiskelua, työnhakua ja työssä toimimista. Vertaisohjaajat kokivat itsekin oppineensa uusia asioita, ja samalla heidän omat digitaitonsa olivat kehittyneet. Ohjaajien mukaan he oppivat huomioimaan vertaisryhmäläisten yksilöllisen etenemisen ja kunnioittamaan jokaista yksilönä. Yksittäisen oppijan edistyminen omalla tasollaan oli tärkeämpää kuin ryhmän nopea eteneminen.

Ohjaajat ymmärsivät, kuinka tärkeää kunkin oli saada itselle räätälöityä oppimisen tukea ja apua.

”Heikommat digiosaajat minun mielestäni saivat itsevarmuutta tästä, että heidä toiminta onnistuu. Kehuin ja kannustin, he ottivat sen vastaan ja mielekkäästi suorittivat tehtäviä. Ajattelen, että he oppivat paljon uutta. Myös he joiden taito oli parempi ja saivat mahdollisuuden laajentaa osaamistaan." (Ohjaaja 3)

Vertaisohjaajien taustojen ja aikaisemman osaamisen heterogeenisuus osoittautui vahvuudeksi vertaisryhmiä ohjattaessa. Ohjaajaparit sekä oppivat toisiltaan että täydensivät toisiaan erilaisten taitojensa ja henkilökohtaisten ominaisuuksiensa ansiosta.
"Ohjaajaparin kanssa oli tosi mukava tehdä yhteistyötä. Hyvin jaroimme työtä keskenään." (Ohjaaja 5)

Ohjaajien mukaan vertaisryhmän toiminnassa tärkeää oli toisten kunnioittaminen ja arvostaminen, ystävällinen ja myönteinen asenne sekä hyvät vuorovaikutustaidot ja oma-aloitteisuus. Yksi ohjaaja nosti vastauksessaan esille myös huumorin merkityksen. Ohjaajat oppivat arvostamaan hyvää viestintää ja hyviä sosiaalisia taitoja myös tilanteessa, jossa toimintaan osallistuvien henkilöiden kulttuuritaustat olivat erilaisia.

Vertaisohjaajat eivät pitäneet vertaisryhmien kokoa ohjaustoiminnan kannalta merkittävänä. Muutama ohjaaja joutui esimerkiksi ohjaamaan yksin suurta ryhmää yhden kokoontumisillan ajan, kun ohjaajapari oli sairastunut. Muutamat vertaisohjaajat oivalsivat antaa tilaa vertaisryhmäläisten keskinäiselle yhteistyölle ja mahdollistivat näin vuorovaikutuksen vertaisoppijoiden kesken. Vertaisohjaajien hanketyöntekijöiden kanssa ennalta laatimat suunnitelmat kokoontumiskertojen sisällöistä muuttuivat ryhmän tason ja tarpeiden mukaan vertaistoiminnan kuluessa. Vertaisohjaajat joutuivat käytännössä huomaamaan, ettei ohjausta voi toteuttaa ohjaajan ehdoilla, vaan sen on oltava opiskelijan tarpeista lähtevää.

\section{OHJAAJAROOLIN OMAKSUMINEN JA VASTUUN OTTAMINEN}

Vertaisohjaajilla oli haasteellinen tehtävä, koska käytettävissä oleva aika oli lyhyt ja osallistujien taidot ja kulttuuritaustat erilaisia. Toiminta toteutettiin lisäksi kielellä, joka oli sekä ohjaajilla että ryhmäläisillä vielä kehitysvaiheessa. Vertaisohjaajina monet omaksuivat roolin, jossa he sovelsivat käytäntöön Suomessa vallitsevaa oppimiskäsitystä, vaikka lähtömaasta saatu oppimisen malli olisi ollut hyvinkin autoritäärinen ja opettajakeskeinen.

Ohjaajien perehdytysjakso oli suppea, koska hankkeen pääpaino oli vertaisuuden toteutumisessa. Ohjaajaparit omaksuivat kuitenkin melko nopeasti itsenäisen ohjaajaroolinsa ja tukeutuivat vain harvoin hanketyöntekijöiden apuun. Vaikka ohjaajat olivat ennalta laatineet yhdessä hanketyöntekijöiden kanssa alustavan ohjelman, suunnitelmat muuttuivat ryhmän toiminnan 
aikana osallistujien tason ja tarpeiden mukaan. Ohjaajilta vaadittiin siksi nopeaa reagointikykyä, kehittyneitä vuorovaikutustaitoja, kärsivällistä otetta ja kykyä tarvittaessa improvisoida.

Useimpien ohjaajien motivaatio pysyi koko ajan hyvänä. He ymmärsivät vastuunsa ja roolinsa opiskelijoiden oppimisprosessin tukijoina, mutta olivat myös sisäistäneet opiskelijalähtöisen tavan oppia ja antoivat tilaa vertaisoppimiselle. Joillakin ohjaajilla sovitut matkat tai muut tehtävät hankaloittivat sitoutumista vertaisryhmän toimintaan. Mitä vähemmän toimintaan osallistuu, sitä vähäisempi vaikutus kokemuksella on osallisuuden tunteen syntymiseen.

Suuri osa maahanmuuttajista on Suomeen muutettuaan joutunut sopeutumaan täysin erilaisiin oloihin kuin lähtömaassa, oppimaan uusia taitoja ja koettelemaan rajojaan monin tavoin. Maahanmuuttajuuden kokeminen kehittää kykyä asettua niiden asemaan, jotka joutuvat aloittamaan uusien asioiden oppimisen aivan alusta. Erilaisuuden hyväksyminen, toisten kannustaminen ja tukeminen kumpuavat siten omista kokemuksista eivätkä päälle liimatusta teoriasta. Monet kunnianhimoisesti tulevaisuuteen suhtautuvat maahan muuttaneet osoittautuvat haasteissa joustaviksi ja muuntautumiskykyisiksi. He eivät pelkää kokeilla asioita, joista kokevat saavansa hyötyä itselleen.

\section{HENKINEN KASVU JA ITSETUNNON VAHVISTUMINEN}

Vertaisohjaajat hyötyivät ohjaajan roolissa toimimisesta monin tavoin. Ohjaaja oppi joissakin tapauksissa yhtä paljon tai jopa enemmän kuin ohjattavansa. Kokemus vertaisohjaajuudesta antoi osallistujille tulevaisuuden työelämässä arvostettavia tietoja, taitoja ja kokemuksia sekä vahvisti tulevaisuudessa yhä enemmän painotettavia ominaisuuksia, kuten paineensietokykyä, luovuutta ja joustavuutta.

Aikuiset maahanmuuttajat oppivat kielen yhteistyön ja interaktiivisen toiminnan kautta, ja opiskelu jatkuu koko elämän ajan (Suni 2011, 11). Vertaisryhmässä suomea käytettiin erilaisissa vuorovaikutustilanteissa, minkä vuoksi ohjaajien ja ryhmäläisten kielitaito vahvistui. Kielen oppiminen on tuloksekkainta silloin, kun kohteena on oppijan kokemus- maailmaan välittömästi liittyvä tilanne (Suni 2011).

Suomen kielen hallitseminen on maahanmuuttajille tärkeä itsetuntoon vaikuttava tekijä. Haasteisiin tarttuminen ja vastuullisista tehtävistä suoriutuminen vahvistivat vertaisohjaajien itsetuntoa. Digipolku töihin -hankkeen vertaistoiminta oli ajallisesti liian lyhyt, jotta kielitaito olisi ehtinyt merkittävästi kehittyä. Vertaisohjaajuus tarjosi kuitenkin mahdollisuuden testata taitoja aidoissa vuorovaikutustilanteissa, joissa oli kuitenkin saatavilla tukea.

\section{VERTAISOHJAUS KOTOUTUMISEN EDISTÄJÄNÄ}

Maahanmuuttajien kotoutumisen yleiset tavoitteet ovat osallisuus ja aktiivisena vaikuttajana toimiminen suomalaisessa yhteiskunnassa (Laki kotoutumisen edistämisestä 1386/2010, 1 \$). Kotoutuminen on yksilön henkilökohtaisesti kokema prosessi, joka toteutuu käytännössä erilaisten polkujen kautta.

Monet maahanmuuttajille suunnatut hankkeet pyrkivät lisäämään kohderyhmän osallistumista koulutuksiin tai työllistymistä tukeviin toimiin. Tällöin ne ovat usein kotouttamistoimia, joissa osallistuja on kotouttamisesta vastuussa olevan viranomaisen toimien kohde. Osallisuuden kokemukseen tarvitaan kuitenkin aina ympäristöstä tulevaa myönteistä palautetta ja siitä johtuvia hyväksytyksi tulemisen, pystyvyyden ja onnistumisen tunteita.

Koska maahanmuuttajat ovat monesti joutuneet Suomeen muuttaessaan jättämään taakseen sukulaisensa, ystävänsä ja työyhteisönsä, heillä on suuri tarve solmia uusia ihmissuhteita ja luoda verkostoja. Vertaisohjaajat sitoutuivat hankkeen tavoitteisiin, joilla pyrittiin parantamaan maahanmuuttajien asemaa työmarkkinoilla, pääsyä ammatilliseen koulutukseen ja siten edistämään kotoutumista. Sitoutumisen myötä he kokivat osallisuutta suomalaisessa yhteiskunnassa.

Vertaisohjaajuus vaikutti myönteisesti ohjaajien käsitykseen itsestä, omista kyvyistä ja mahdollisuuksista toimia tulevaisuudessakin vastaavia taitoja vaativissa tehtävissä. Vertaistoiminnasta selviäminen suomen kielellä antoi maahanmuuttajille pystyvyyden tunteita, synnytti osallisuutta toimintaan, jossa he ovat tottuneet näkemään kantasuomalaisia - osallisuutta suomalaisuudesta. Tällä voi katsoa olevan 
tärkeä merkitys heidän kotoutumisprosessilleen.

Kotouttamistoimia suunniteltaessa vertaisohjausta ja sitä koskevaa vertaisryhmätoimintaa voi Digipolku töihin -hankkeen ohjaajien kokemusten perusteella suositella hyödynnettäväksi vielä enemmän. Vertaisohjauksen kaltaiseen toimintaan tulisi vastuuttaa maahanmuuttajia, joilla on tarvittavat valmiudet, motivaatio ja kyky pitkäjänteiseen sitoutumiseen.

Tulevaisuudessa muuttuvan työelämän tekijöille asettamaan ammatilliseen kompetenssiin kuuluvat muun muassa hyvät vuorovaikutus- ja tiimityötaidot, kulttuuritietoisuus, kyky reagoida nopeasti muutoksiin ja oppia uutta sekä taito käyttää sujuvasti digitaalista teknologiaa.

Yhteisten päämäärien eteen toimiminen yhdessä eri kulttuureista tulevien kanssa on tulevaisuuden työelämässä erityisen tärkeää. Maahanmuuttajilla olettaisi näillä kriteereillä olevan työmarkkinoilla jopa etulyöntiasema valtaväestöön verrattuna, kunhan työnantajat oivaltavat heidät voimavarana.

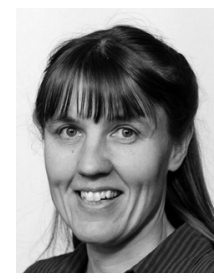

TANJA PÄÄLLYSAHO

$\mathrm{KL}, \mathrm{FM}$, kouluttaja

Seinäjoen koulutuskuntayhtymä Sedu

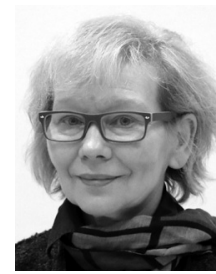

MARJA-LIISA SAUNELA

kouluttaja

Seinäjoen koulutuskuntayhtymä Sedu

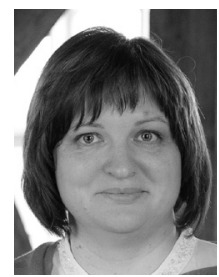

\section{MINNA PESONEN}

KM, koulutussuunnittelija

Oulun yliopisto

(projektipäällikkö

Opintokeskus Sivis

31.12.2018 asti)

\section{LÄHTEET}

Digipolku töihin. Verkkosivusto. https://www.ok-sivis.fi/ digipolku-toihin.html (15.1.2019).

Fawcett, L. M. \& Garton, A. F. (2005). The effect of peer collaboration on children's problem-solving ability. British Journal of Educational Psychology 75(2), 157-169.

Fields, M. (2012). Mitä on vertaisoppiminen? Teoksessa Fields, M. \& Plathan, S. (toim.) Tietoa, taitoja ja hyvää fiilistä - vertaisoppimisen taustaa ja kokemuksia järjestötoiminnassa. Helsinki: OK-opintokeskus, 8-17.

Kentz, M.-B., Sintonen, S. \& Lipponen, L. (2017). Vertaisoppiminen digitaalisessa toimintaympäristössä. Tapaustutkimus kahden viisivuotiaan Minecraftluomisesta. Kasvatus \& Aika 11(1), 54-68. https:// journal.fi/kasvatusjaaika/article/view/68705/30126 (10.1.2019).

Laki kotoutumisen edistämisestä 1386/2010. https:// www.finlex.fi/fi/laki/ajantasa/2010/20101386 (21.1.2019).

Mäkinen, M. \& Sihvonen, M. (2016). Tietoteknisten taitojen puutteet maahanmuuttajien kotoutumisen haasteena. Aikuiskasvatus 36(4), 279-287.

Nivala, E. \& Ryynänen, S. (2013). Kohti sosiaalipedagogista osallisuuden ideaalia. Sosiaalipedagoginen aikakauskirja 14, 9-41.
Nylund, M. (2005). Vertaisryhmät kokemusten ja tiedon jäsentäjinä. Teoksessa Nylund, M. \& Yeung, A. B. (toim.) Vapaaehtoistoiminta - anti, arvot ja osallisuus. Tampere: Vastapaino, 195-213.

Opetushallitus. (2012). Kielitaidon tasojen kuvausasteikko. http://www.oph.fi/download/111628_KIELITAIDON_ TASOJEN_KUVAUSASTEIKKO.pdf (22.1.2019).

Pöyhönen, S., Tarnanen, M., Kyllönen, T., Vehviläinen, E.-M. \& Rynkänen, T. (2009). Kielikoulutus maahanmuuttajien kotoutumiskoulutuksessa. Tavoitteet, toteutus ja hallinnollinen yhteistyö. Jyväskylä: Jyväskylän yliopisto, Soveltavan kielentutkimuksen keskus.

Suni, M. (2011). Missä ja miten maahanmuuttajat kehittävät ammatillista kielitaitoaan? Ammattikasvatuksen Aikakauskirja 13(2). Työelämän ja ammatillisen koulutuksen monikulttuuristuminen. Helsinki: OKKA-säätiö, 8-22.

SunWolf. (2008). Peer Groups. Expanding our study of small group communication. London: Sage.

Tietoyhteiskunnan kehittämiskeskus TIEKE. (2018). Tiviittori. https://www.tieke.fi/display/Tiviittori/ Testien+esittelyt (20.1.2019).

Topping, K. J. (2005). Trends in Peer Learning. Educational Psychology 25(6), 631-645. 